\title{
Bobellis oliveri gen. et sp. nov. from the Silurian of North Greenland (Laurentia) and the systematic position of pycnomphaline gastropods
}

John S. Peel

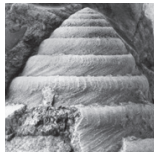

The gastropod Bobellis oliveri gen. et sp. nov. is described from carbonate mounds of the Samuelsen Høj Formation (early Silurian) within the Washington Land Group of North Greenland (Laurentia). It displays a profound adapertural swing of the growth lines across the upper whorl surface in the multi-whorled trochiform shell; the umbilicus is closed by a prominent funicle. Bobellis oliveri is assigned to the Family Pycnomphalidae (Ordovician-Devonian; nom. transl. Subfamily Pycnomphalinae Peel, 1984) which is transferred to the Euomphaloidea, alongside the morphologically similar Omphalotrochidae (Devonian-Permian). In pycnomphalids the umbilicus is usually partially or completely closed by a prominent circumbilical funicle while the umbilicus of omphalotrochids is generally open. $\bullet$ Key words: Silurian, North Greenland, Laurentia, Gastropoda, Pycnomphalidae.

Peel, J.S. 2019. Bobellis oliveri gen. et sp. nov. from the Silurian of North Greenland (Laurentia) and the systematic position of pycnomphaline gastropods. Bulletin of Geosciences 94(2), 125-136 (4 figures). Czech Geological Survey, Prague. ISSN 1214-1119. Manuscript received January 23, 2019; accepted in revised form April 12, 2019; published online May 6, 2019; issued June 17, 2019.

John S. Peel, Department of Earth Sciences (Palaeobiology), Uppsala University, Uppsala, Sweden; john.peel@pal.uu.se

In most mobile marine gastropods the plane of the shell aperture is tangential to the final whorl and oriented parallel to the substrate in life. Tangentialism may be produced in several different ways (Wagner 2002) but it enables clamping of the shell down over the body when the animal is disturbed (Linsley 1977); it can be viewed as one of the earliest responses in gastropods to predation or environmental stress. In gastropods where the aperture is not tangential, the plane of the aperture lies along a radius from the shell coiling axis and the shell aperture cannot clamp down against the substrate (Linsley 1977, McNair et al. 1981). At the present day, gastropods with radial apertures are uncommon and include cemented and uncoiling forms such as the filter-feeding vermetids, where the shell aperture is closed by an operculum capable of regeneration (Hadfield 1970). In architectonicids the regularly coiled shell is attached to its cnidarian host with mucous threads and the animal feeds on the scleractinian corals with an unusually long, extensible proboscis (Robertson in Linsley 1977; Robertson 1967, 1970).

In contrast, gastropods with radial apertures are relatively common in the Palaeozoic, including groups such as the macluritoids and euomphaloids (Knight et al. 1960, Frýda et al. 2008, Frýda 2012, Bouchet et al. 2017), although Linsley \& Kier (1984) suggested that these were not true gastropods (see also Bouchet et al. 2005, Frýda et al. 2008). Typically, such forms are low spired with an open umbilicus, a shell morphology that is common in the Palaeozoic (Wagner \& Erwin 2006). Some are even open coiled (Yochelson 1971, Linsley \& Yochelson 1973, Peel 1975, Linsley 1978). Many have been interpreted as filter feeders and often had a prominent operculum (Yochelson \& Linsley 1972, Yochelson 1979, Rohr \& Boucot 1984, Horný 1995, Rohr \& Gubanov 1997, Rohr \& Yochelson 1999, Rohr 2004, Rohr et al. 2004).

This paper describes a new gastropod, Bobellis oliveri gen. et sp. nov., from the lower Silurian of North Greenland (Fig. 1) in which the aperture is radial. Similar gastropods with a cyrtoconoid shell form and orthocline to opisthocline outer lip have been assigned to the Anomphalidae Wenz, 1938 and the Omphalotrochidae Knight, 1945 (Knight et al. 1960; Wagner 2002; Bouchet et al. 2005, 2017) and the description of Bobellis prompts discussion of the relationships of Palaeozoic gastropods that have been assigned to these families. Bobellis is closely related to Grantlandispira Peel, 1984, originally described also from the lower Silurian of North Greenland (Peel 1984; Fig. 2), and is readily placed together with the latter genus in the Subfamily Pycnomphalinae Peel, 1984. However, Pycnomphalinae is elevated herein to family status and removed from the trochoidean Anomphalidae. Pycnomphalidae and Omphalotrochidae are recognized as separate families with Euomphaloidea. 


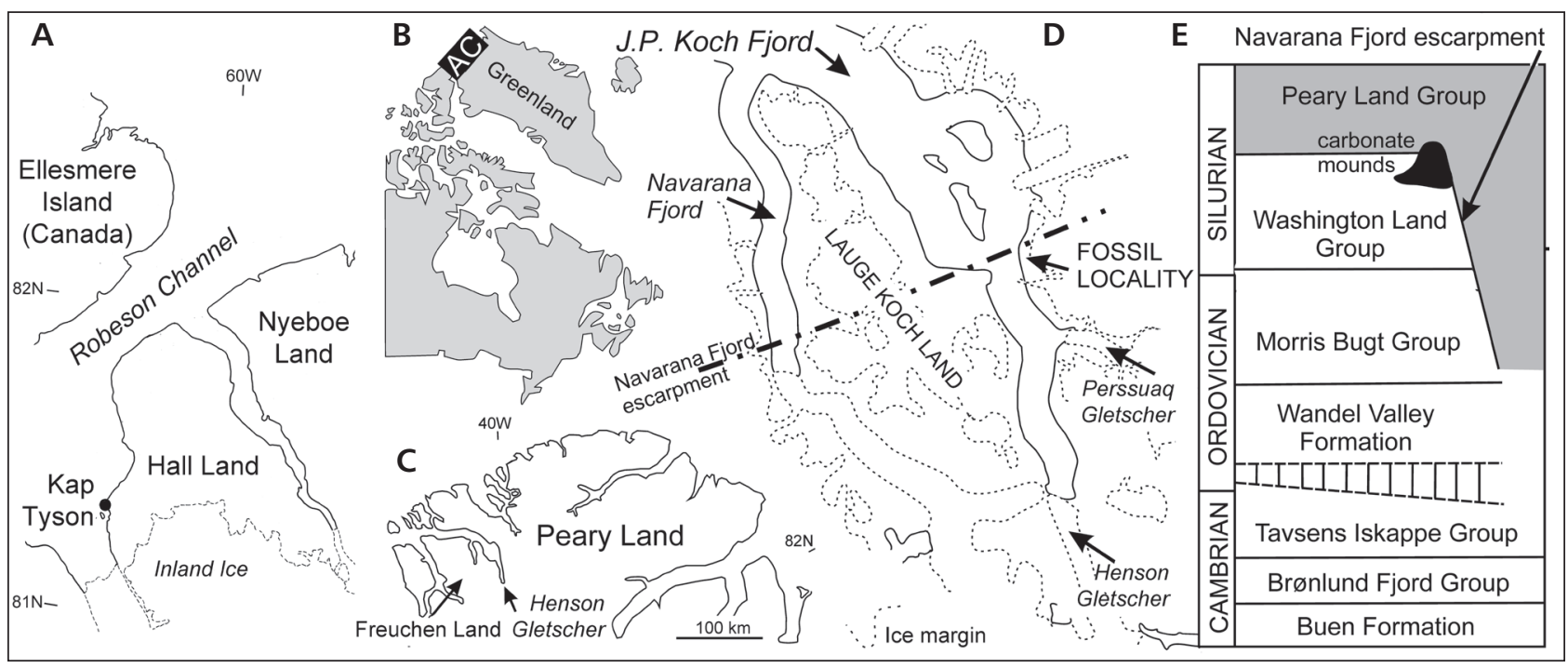

Figure 1. Derivation of samples. • A-D - maps showing the collection locality of Grantlandispira christiei Peel, 1984 at Kap Tyson in Hall Land (A) and of Bobellis oliveri gen. et sp. nov., east of J.P. Koch Fjord, Peary Land (D). • E - Cambrian-Silurian stratigraphic nomenclature around southern J.P. Koch Fjord locating carbonate mounds yielding Bobellis oliveri.

\section{Derivation of material}

All specimens of Bobellis oliveri gen. et sp. nov. are derived from GGU samples collected by J.S. Peel on $10^{\text {th }}-12^{\text {th }}$ August 1985, on the eastern side of J.P. Koch Fjord, Peary Land, North Greenland $\left(82^{\circ} 30^{\prime} \mathrm{N}, 41^{\circ} 16.5^{\prime} \mathrm{W}\right.$, altitude about $600 \mathrm{~m}$ a.s.1.) from carbonate mounds of early Silurian age that occur at the top of the Washington Land Group (Fig. 1B-E). The mounds are located near the northern rim of a Cambrian-Silurian carbonate platform that terminates in a profound escarpment, the Navarana Fjord escarpment (Higgins et al. 1991). While representing a major down-to-basin tectonic feature in the geological evolution of North Greenland (Peel \& Sønderholm 1991, Higgins et al. 1991, Surlyk 1991, Ineson \& Peel 2011), the lineament shows little evidence of movement during the Late Ordovician and Silurian, although the geomorphological feature persisted as a steep scarp about $500 \mathrm{~m}$ in height. Trough siliciclastic sediments of the Peary Land Group accumulated rapidly against the face of the escarpment before drowning the southern carbonate platform in the late early Silurian. The associated fauna in the carbonate mounds consists of a rich assemblage of gastropods, corals and brachiopods; trilobites from the same locality were described by Hughes \& Thomas (2015).

Institutional abbreviations. - GGU - Grønlands Geologiske Undersøgelse, the Geological Survey of Greenland, Copenhagen, Denmark; MGUH - the palaeontological type collection of the Natural History Museum of Denmark, Copenhagen, Denmark; PMU - the palaeontological type collection of the Museum of Evolution, Uppsala University, Sweden.

\section{Classification}

Previous work. - The Family Omphalotrochidae Knight, 1945 was placed within the Superfamily Euomphaloidea (as Euomphalacea) de Koninck, 1881, Suborder Macluritina Cox \& Knight, 1960 by Knight et al. (1960), while Anomphalidae Wenz, 1938 was located within the Superfamily Anomphaloidea Wenz, 1938 (as Anomphalacea) of the Suborder Trochina Cox \& Knight, 1960.

Peel (1984) abandoned Anomphaloidea and placed Anomphalidae as a family within the Superfamily Trochoidea Rafinesque, 1815 (as Trochacea), following McLean (1981). He proposed a new Subfamily Pycnomphalinae within Anomphalidae to contain gastropods in which the outer lip varies from near orthocline to opisthocline, including Pycnomphalus Lindström, 1884 and a new genus, Grantlandispira Peel, 1984 from the lower Silurian of Greenland. Other anomphalid genera recognized by Knight et al. (1960) were placed by Peel (1984) within the Subfamily Anomphalinae on account of their generally prosocline outer lip.

Anomphalidae was recognized as a monophyletic family within Euomphaloidea by Wagner (2002) who followed Kase (1989) in suggesting that Labrocuspis Kase, 1989 and some genera assigned to Omphalotrochidae might belong here. Wagner $(2002$, p. 79) placed Grantlandispira as a synonym of Trochomphalus Koken $\&$ Perner, 1925. However, this genus was later considered to be a planitrochid in the on-line database Fossilworks, gateway to the Paleobiology Database (http://www. fossilworks.org), as updated by P.J. Wagner during 2017, while Grantlandispira was placed as a synonym of Pycno- 
trochus Perner, 1903. Turbocheilus Perner, 1907 was synonymized with Pycnomphalus, as also (tentatively) were Nematrochus Perner, 1903, Pycnotrochus and Isfarispira Gubanov, Peel \& Pianovskaya, 1995. The synonymies largely reflected Wagner's (2002) philosophy of eliminating monotypic genera from his phylogenetic classification of Lower Palaeozoic gastropods. Wagner (2002) commented that true omphalotrochids appear to have originated from within the Family Euomphalidae, although Knight et al. (1960) suggested their derivation from forms similar to the Silurian Centrifugus Bronn, 1834. Yochelson (1956, p. 201) commented that 'it is impossible to construct any meaningful family phylogeny at this time'.

Bouchet et al. (2005) considered Anomphalidae to be certainly basal Gastropoda but made no assignment to superfamily. In a study of Triassic fossils from Vietnam, Kaim et al. (2014) re-ranked Anomphalidae as the Subfamily Anomphalinae of the Family Turbinidae Rafinesque, 1815, a family which Knight et al. (1960) only recorded from Triassic-Recent, while Anomphalus Meek \& Worthen, 1867 was originally described from the Carboniferous (Knight 1941). Nützel in Nützel \& Nakazawa (2012) interpreted Anomphalidae as Turbinoidea Rafinesque, 1815 but Nützel \& Ketwetsuriya in Ketwetsuriya et al. (2016) placed the family within Trochoidea. This latter placement was maintained by Bouchet et al. (2017, p. 337).

The placement of Omphalotrochidae in the Superfamily Euomphaloidea (as Euomphalacea) of the archaeogastropod Suborder Macluritina by Knight et al. (1960) was accepted by Bouchet et al. (2005) but they considered euomphaloideans to be of uncertain position within the molluscs. This tentative interpretation as gastropods may have been a reflection of the placement of euomphaloideans within a new Class Paragastropoda by Linsley \& Kier (1984). Bandel \& Frýda (1998) elevated Euomphaloidea to a new Subclass Euomphalomorpha (not class as stated by Bouchet et al. 2005, p. 271), but Nützel (2002) did not maintain the subclass. In reviewing Palaeozoic gastropods, Frýda et al. (2008) considered Euomphalomorpha to be possibly ancestral to patellogastropods, although the origin and geological range of the latter clade is controversial (Lindberg 1988, Ponder \& Lindberg 1997, Bouchet et al. 2005, Nakano \& Ozawa 2007, Frýda et al. 2008, Frýda 2012, Aktipis \& Giribet 2010). Bouchet et al. (2017, p. 333) regarded omphalotrochids as 'Palaeozoic basal taxa that are certainly Gastropoda', placing them within the Superfamily Euomphaloidea White, 1877.

The on-line databases Fossilworks, gateway to the Paleobiology Database and WMSDB - Worldwide Mollusc Species Database (http://www.bagniliggia. it/WMSD/HtmFamily/OMPHALOTROCHIDAEL. $\mathrm{htm}$ ), placed respectively 13 and 14 genera within Om- phalotrochidae, the only family placed within Omphalotrochoidea, but the reasons for including several of these genera, such as the holopeiform Archaeosphera Heidelberger \& Bandel, 1999 (see also Heidelberger 2007), Cinclidonema Knight, 1945 and Sylvestria Heidelberger, 2001, close to Omphalotrochus are elusive.

In Fossilworks, Anomphalidae is listed as containing the Subfamily Pycnomphalinae with Isfarispira, Pycnomphalus, Pycnotrochus, (with Grantlandispira as a junior synonym) and Turbocheilus Perner, 1907, although Isfarispira is separately referred to Omphalotrochidae (placement cited as following Peel 2018). Peel (2018) considered Isfarispira to be a member of the pycnomphaline-omphalotrochid group and unrelated to anomphalines. To these genera, within Pycnomphalinae, WMSDB adds several genera included within Anomphalidae by Knight et al. (1960), Peel (1984, as Anomphalinae) and Fossilworks (as non-pycnomphaline anomphalids).

Discussion. - Three families are recognized herein. The placement of Anomphalidae within Trochoidea and Omphalotrochidae within Euomphaloidea reflects current opinions in published literature, discussed above. The fundamental difference in the nature of the outer lip noted by Peel (1984) promotes removal of Pycnomphalinae from Anomphalidae but the relationship between pycnomphalines and omphalotrochines is less clear. Both share the presence of a sub-sutural sinus in most constituent genera, although an emargination occurs in this position high on the upper whorl surface in several euomphaloideans and even in some unrelated pleurotomariiform, holopeiform and high spired gastropods (Knight et al. 1960, Harper 2016).

Pycnomphalinae is here elevated to a family, Pycnomphalidae (Ordovician-Devonian), and transferred to Euomphaloidea alongside Omphalotrochidae (Devonian-Permian). The rotelliform to cyrtoconoid shells of pycnomphalids usually develop a prominent funicle which restricts or closes the umbilicus. In omphalotrochids, the shell form is often gradate, even tending towards trochiform, and the umbilicus is usually open. Omphalotrochids are typically Permian in age but occur also in the latest Carboniferous (Yochelson 1956). However, several Devonian and Carboniferous taxa have been referred to the family but forms such as Orecopia Knight, 1945 Bassotrochus Tassell, 1978, Labrocuspis and Pycnotrochus are here placed within Pycnomphalidae. Cinclidonema Knight, 1945 is considered to be a holopeid, and Trochonemopsis Meek, 1873 is interpreted as a trochonematid, as suggested by Knight et al. (1960).

Of particular interest is Pseudomphalotrochus Blodgett, 1992, originally described from the Devonian of Alaska (Blodgett 1992, p. 141) as an omphalotrochid "but differing primarily [from Omphalotrochus] in the presence of 
a strong basal angulation bearing a prominent circumbilical ridge". Blodgett (1992) considered it likely that Omphalotrochus was derived from Pseudomphalotrochus but noted the significant stratigraphic gap between the two. The whorl profile of Pseudomphalotrochus is strongly gradate, with angular, almost perpendicular, transitions between the upper whorl surface, the outer whorl surface, the base and the umbilical wall. This, together with the open umbilicus which lacks the prominent funicle or callus seen in most pycnomphalids, argues against assignment of Pseudomphalotrochus to Pycnomphalidae. Pseudomphalotrochus is tentatively retained within Omphalotrochidae, although the supposed Devonian range of this late Carboniferous to typically Permian group (Yochelson 1956) is otherwise mainly based on Orecopia, following Knight (1945). Orecopia is regarded herein as a pycnomphalid. Pseudomphalotrochus may represent a separate, earlier, branch from euomphaloidean stock than Omphalotrochus and its immediate relatives such as Babylonites Yochelson, 1956 and Coronopsis Waterhouse, 1963.

\section{Systematic palaeontology}

This published work and the nomenclatural acts it contains have been registered in ZooBank: http:// zoobank.org/References/31053BC7-F67A-4871-BC10OB7502CBF990.

Phylum Mollusca Cuvier, 1797

Class Gastropoda Cuvier, 1797

Superfamily Euomphaloidea White, 1877

Family Pycnomphalidae Peel, 1984

nom. transl. Subfamily Pycnomphalinae Peel, 1984

Diagnosis. - Rotelliform to cyrtoconoid gastropods with the subradial aperture varying from near orthocline to strongly opisthocline on the upper whorl surface below a sub-sutural sinus. Umbilicus often partially or completely closed by a prominent circumbilical funicle extending adaxially from the base of the whorl (emended from Peel 1984).

Discussion. - Peel (1984) proposed Pycnomphalinae to include Pycnomphalus, his new genus Grantlandispira and possibly Turbocheilus, although the latter was considered to be a junior synonym of Pycnomphalus by Wagner (2002, p. 79).

The eponymous genus Pycnomphalus occupies a basal morphological position within the family in that neither the sub-sutural sinus nor the circumbilical funicle are strongly developed in the type species, Pycnomphalus obesus Lindström, 1884, from the Silurian of Gotland, Sweden. The latter is morphologically close to Pycnomphalus borkholmiensis Koken, 1897 from the Late Ordovician of Estonia. Thus, pycnomphalids range from the Late Ordovician into the Devonian where the family is represented by the well-known Orecopia which closely resembles Grantlandispira and Bobellis gen. nov., both from the lower Silurian of North Greenland. These three genera frequently show a decrease in the incremental angle through growth of the multi-whorled shell to produce a cyrtoconoid form in larger specimens.

Lindström (1884) described three species of Pycnomphalus from the Silurian of Gotland. Growth lines indicate that the essentially orthocline outer lip in the more rotelliform Pycnomphalus obesus, the type species, has a slight sub-sutural concavity (Knight 1941); the umbilicus is also partially closed by a broad funicle. The whorl periphery is well rounded, whereas it is acutely angular in Pycnomphalus acutus Lindström, 1884 [now assigned to ?Grantlandispira acuta (Lindström, 1884)] and Pycnomphalus trochiformis Lindström, 1884, also from the Silurian of Gotland. The periphery in ?Grantlandispira acuta is extended into a flange which recalls the supra-sutural cord of Grantlandispira christiei (Fig. 2B, C), although the former is lower spired and with a less prominent circumbilical funicle. Pycnomphalus trochiformis is similar in shell shape to Bobellis oliveri gen. et sp. nov., but lacks the prominent sub-sutural shoulder of the latter (Fig. 3B).

Pycnomphalus borkholmiensis, as illustrated by Koken \& Perner (1925, pl. 32, figs 1-6, 9) from the Late Ordovician of the Baltic Region, has less inflated whorls than Pycnomphalus obesus and its funicle is more acute. Both species have fewer whorls than Pycnomphalus colemani Parks, 1915, from the lower Silurian of Canada which is rotelliform, but differs from the type species in its lower spired shell, greater number of whorls and the presence of a well-developed funicle. It is closely similar to the better known Pycnomphalus solaroides (Hall, 1852), as described by Whiteaves (1895, pl. 13, figs 3-8) from the Silurian Guelph Formation of southern Ontario, Canada. The latter has numerous slowly expanding whorls and the umbilicus is completely closed by the prominent circumbilical funicle. Growth lines on the upper whorl surface appear to be orthocline whereas those on the base are concave adapically, as in Bobellis oliveri (Fig. 3M).

Turbocheilus, as described by Knight (1941) from the Bohemian Silurian, is more globose and with fewer whorls than several species referred to Pycnomphalus. A slight sub-sutural sinus is developed and the umbilicus is completely closed by callus.

Grantlandispira has a cyrtoconoid shell in which the sides of the spire are uniformly convex in lateral profile (Fig. 2B, D). The growth lines forming the lower margin 


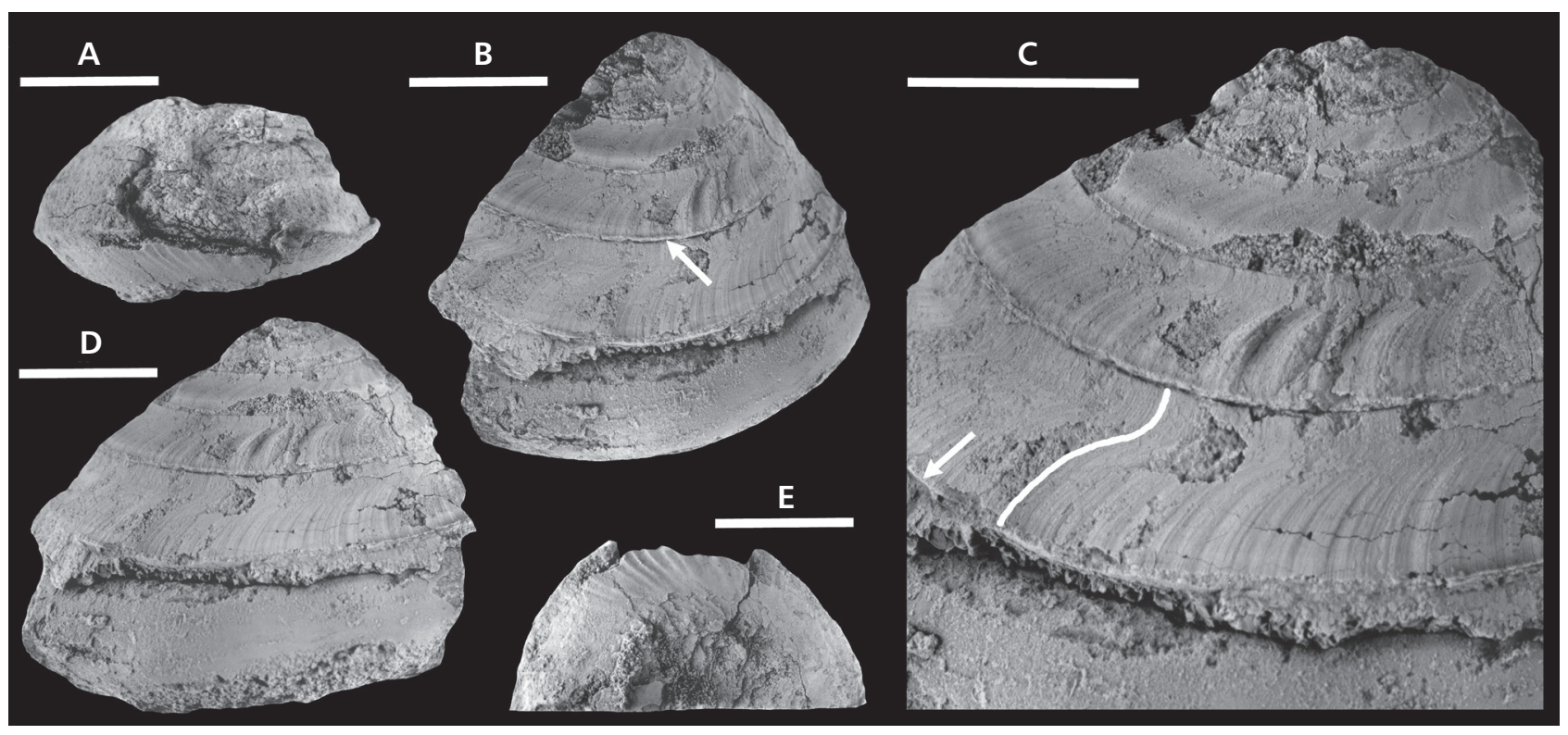

Figure 2. Grantlandispira christiei Peel, 1984. Silurian, Washington Land Group, Offley Island Formation, Kap Tyson, Hall Land, North Greenland; A, E - MGUH 16567 from GGU sample 82619, paratype, in lateral and basal views; B-D - MGUH 16566 from GGU sample 82626, holotype, in oblique lateral $(\mathrm{B}, \mathrm{C})$ and lateral views (D). Arrows indicate narrow peripheral cord, while the shape of growth lines on the upper whorl surface is inked in C. All specimens coated with ammonium chloride sublimate prior to photography. Scale bars $=10 \mathrm{~mm}$.

of the sinus sweep strongly forward across the upper whorl surface in contrast to the near orthocline shape in Pycnomphalus and Turbocheilus.

The cyrtoconoid shell form and prominent circumbilical funicle (Knight 1945) motivate transfer of Orecopia to Pycnomphalidae. It is morphologically close to Grantlandispira and Bobellis gen. nov. but the sinus is broad and much less strongly asymmetrical than in the last two genera.

Other possible pycnomphalids include Isfarispira, from the Silurian of central Asia and Laurentia (Gubanov et al.1995, Peel 2018), Labrocuspis from the middle Devonian of Queensland and Japan (Heidecker 1959, Kase 1989), and Fujispira Kase \& Nishida, 1986 from the middle Devonian of Japan (Kase \& Nishida 1986).

Isfarispira septata Gubanov, Peel \& Pianovskaya, 1995, from the Chorkuin Formation (Llandovery-Wenlock boundary) of the Pschemack Mountains, Kyrgyzstan, was tentatively assigned to Omphalotrochidae by Gubanov et al. (1995). In revising Isfarispira perlata (Hall, 1852) from the Guelph Formation of Laurentia, Peel (2018) left the position of Isfarispira unresolved within a pycnomphaline-omphalotrochid group. On account of its radial aperture, multi-whorled form and prominent circumbilical funicle Isfarispira is tentatively assigned herein to Pycnomphalidae.

Labrocuspis has a massively calcified shell in which the umbilicus appears to be completely closed by callus (Heidecker 1959). Fujispira is not well known but appears to be lower spired, trochiform, with relatively few whorls (Kase \& Nishida 1986). The upper surface of the whorl seems to show a sinus high on the whorl, as in many pycnomphalids and omphalotrochids, but the widely phaneromphalous umbilicus suggests placement in Omphalotrochidae.

Pycnotrochus, from the upper Silurian of Bohemia, is inadequately known on account of its poor preservation, mainly as internal moulds from limestones of the Kopanina Formation, but it appears to be a pycnomphalid. A sinus is apparently present on the sub-sutural ramp and growth lines sweep strongly forward from this, across the upper whorl surface towards the periphery. The umbilicus is almost completely closed (Knight 1941).

Bassotrochus, from the lower Devonian of Victoria, Australia, was considered by Tassell $(1978$, p. 20) to be the oldest occurrence of the Omphalotrochidae described to date but it is here placed within Pycnomphalidae. The whorls vary from slightly adpressed to embracing the previous whorls below the periphery; a broad, shallow, sinus culminates high on the upper whorl surface and the whorl periphery may be extended into a broadly rounded flange. Tassell (1978) remarked that an umbilicus was apparently lacking, but general shell shape suggests that this may be the result of closure by a funicle.

\section{Genus Bobellis gen. nov.}

Type species. - Bobellis oliveri gen. et sp. nov., from the Samuelsen Høj Formation (early Silurian), Washington Land Group, North Greenland. 
Etymology. - It is 50 years since I first met Ellis L. Yochelson (1929-2006) and Robert ('Bob') M. Linsley (1930-2006): my teachers, colleagues and friends. Bobellis commemorates their major contributions to the study of Palaeozoic gastropods.

Diagnosis. - Trochiform, with shallowly convex sides (cyrtoconoid) and a shallowly convex base. Umbilicus largely closed by a spiral funicle, the lower surface of which is confluent with the base of the whorl; parietal deposits forming the funicle extending variably out across the base, decreasing in thickness as the periphery is approached. Whorls strongly adpressed, embracing the previous whorl near the mid-height of the concave outer whorl surface which lies between the angular periphery and the prominent adpressed shoulder; sutures incised. Apertural cross-section sub-quadrate. Outer lip sinuate, the culmination of the sub-sutural sinus occupying the width of the adpressed shoulder; opisthocline growth lines representing the lower margin of the sinus cross the whorl surface towards the peripheral angulation without curvature. Base excavated, with concave growth lines passing from the peripheral angulation towards the funicle. A prominent tongue-like lobe of the apertural margin, corresponding to the peripheral angulation, is thus formed between the sinuses in the upper and basal whorl surfaces. Ornamentation of collabral growth lines with a tendency to become nodose on the shoulder and, to a lesser extent, also on the peripheral angulation.

Discussion. - Bobellis most closely resembles Grantlandispira from the lower Silurian of western North Greenland (Peel 1984; Fig. 2) and Orecopia from the Devonian of North America and Europe (Knight 1945, Pedder 1966). All three genera frequently show a decrease in the incremental angle through growth of the multiwhorled shell to produce a cyrtoconoid (beehive-shaped) shell in larger specimens (Knight 1945, pl. 80, figs 1a, g; Fig. 2A, C, D; Fig. 3B, L). Thus, juvenile shells often appear more lenticular than mature shells. Additionally, massive thickening at the umbilico-basal angulation produces a prominent circumbilical funicle (Fig. 4). Both of these features serve to reduce the relative width of the umbilicus and likely represent adaptations to counteract durophagous predatory attacks. The typically widely phaneromphalous umbilicus of euomphaliform gastropods is vulnerable to shell crushing attacks (Vermeij 1987, Lindström \& Peel 1997, Alexander \& Dietl 2003).

Bobellis is distinguished from Orecopia by its prominent sub-sutural shoulder and more pronounced trochiform shape, although the upper whorl surface may be concave above the periphery in both forms (Knight 1945; Fig. 3). The sinus is less asymmetric in Orecopia than in Bobellis and its culmination is lower on the upper whorl surface. Grantlandispira also lacks the prominent sub-sutural shoulder and peripheral angulation which are well developed in Bobellis. Additionally, growth lines forming the lower margin of the sinus are convex adaperturally and less strongly oblique in Grantlandispira than in Bobellis.

Bobellis resembles Labrocuspis from the middle Devonian of Australia and Japan but the type species, Labrocuspis nodosa Heidecker, 1959, from Queensland has a massively thick shell, fewer whorls and the umbilicus is completely closed by thickening of the umbilical wall (Heidecker 1959). The whorl profile in Labrocuspis nodosa is strongly shouldered, almost gradate, with prominent sub-sutural nodes in the early growth stages. Labrocuspis kobayashii (Kase \& Nishida, 1986) from the middle Devonian Nakazato Formation of Japan (Kase \& Nishida, 1986, Kase 1989) is less shouldered, more smoothly cyrtoconoid in shape, lacking the prominent, cord-like, sub-sutural shoulder of Bobellis. In this respect it resembles Orecopia, to which it was originally assigned by Kase \& Nishida (1986). As in Bobellis, growth lines on the upper whorl surface in both species of Labrocuspis sweep strongly forward towards the aperture, although Bobellis is higher spired and has more whorls.

Fujispira is based on poorly preserved material from the middle Devonian of Japan (Kase \& Nishida 1986). Few whorls are present and the umbilicus is widely phaneromphalous, suggesting placement within Omphalotrochidae. The upper surface of the whorl seems to show a sinus high on the whorl, as in Bobellis, Grantlandispira and Orecopia.

Other species. - Type species only.

\section{Bobellis oliveri sp. nov.}

Figures 3, 4B

Holotype. - PMU 34882 from GGU sample 301325, Samuelson Høj Formation, Washington Land Group, Peary Land, North Greenland.

Paratypes. - Figured: PMU 34883 and PMU 34888 from GGU sample 301325, PMU 34884 and PMU 34885 from GGU sample 301319, PMU 34886 from GGU sample 301324, PMU 34887 from GGU sample 301319. Same locality and horizon as the holotype.

Type horizon and locality. - Samuelsen Høj Formation (early Silurian), Washington Land Group, east side of J.P. Koch Fjord, westernmost Peary Land, North Greenland (Fig. 1).

Material. - More than 20 specimens from the same collections. 


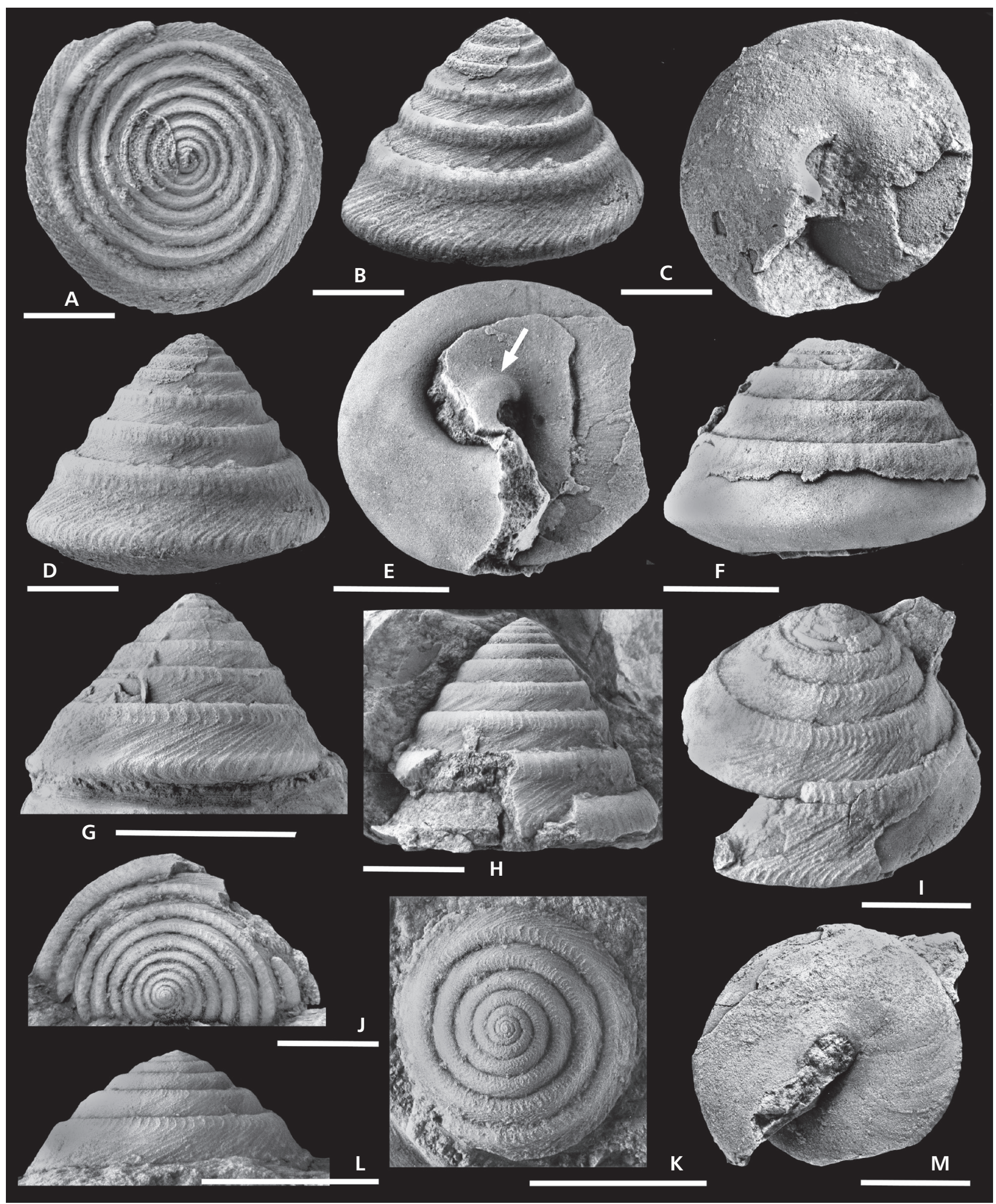

Figure 3. Bobellis oliveri gen. et sp. nov., Silurian, Washington Land Group, Samuelsen Høj Formation, east side of J.P. Koch Fjord, western Peary Land, North Greenland; A-D - PMU 34882 from GGU sample 301325, holotype in apical (A), oblique lateral (B), basal (C) and lateral (D) views; E, F PMU 34883 from GGU sample from GGU sample 301325, paratype in oblique basal (E) and lateral (F) views, with arrow indicating funicular ridge; G - PMU 34884 from GGU 301319, paratype in lateral view; H, J - PMU 34885 from GGU sample 301319, paratype in lateral (I) and apical (J) views; I, M - PMU 34886 from GGU sample 301324, paratype in oblique lateral (I) and basal (M) views; K, L - PMU 34887 from GGU sample 301319, paratype in apical $(\mathrm{K})$ and lateral $(\mathrm{L})$ views. All specimens coated with ammonium chloride sublimate prior to photography. Scale bars $=10 \mathrm{~mm}$. 
Etymology. - For Oliver Jonathan Wilfred.

Diagnosis. - As for genus.

Description. - The type species of Bobellis with about 12 whorls. Shell form varies during ontogeny from high to low trochoidal, such that the height of the aperture ranges from about one third to one half of the total height; the known extremes of variation are illustrated (Fig. 2H, L). The shell is cyrtoconoid with the sides of the spire being shallowly convex, becoming increasingly so as the nucleus is approached; the incremental angle thus decreases during ontogeny.

The protoconch has not been observed directly, but it was not larger than about $0.2 \mathrm{~mm}$. The following three whorls, up to a shell width of about $1.5 \mathrm{~mm}$, are apparently smooth, after which the comarginal ornamentation gradually appears on the upper whorl surface, showing the same general shape as is present during later growth stages; as far as is discernible these earliest whorls only differ in shape from subsequent whorls in the absence of the sub-sutural shoulder (Fig. 2K, L).

The profile of later whorls is sub-quadrate; it is divided into upper and lower surfaces by a broad peripheral angulation located below mid-whorl height. The upper whorl surface is generally concave between the peripheral angulation and a prominent sub-sutural shoulder which represents the zone of adpression against the previous whorl. This band-like zone of adpression is almost half the height of the exposed whorl surface in the spire, and about one third of the height of the outer surface of the final whorl. The suture is therefore deeply incised in detail, almost canaliculate in some specimens. After slight concavity immediately adjacent to the peripheral angulation, the base is shallowly convex in profile as the umbilicus is approached. Delimitation of the floor of the whorl from the prominent circumbilical funicle is generally not possible (but see discussion of parietal deposits below). The umbilicus is essentially wide, but is partly closed by a massive circumbilical funicle extending almost to the axis of coiling in the later growth stages. The funicle is formed from parietal deposits which extend as a sheet across the base of the whorl, the thickness of the sheet decreasing as the whorl periphery is approached; its margin may be thickened and carry a small, rounded, tooth-like ridge (Fig. 3E, arrow).

The aperture is radial with a protruding tongue-like lobe, the adapertural termination of which corresponds to the peripheral angulation. A strongly asymmetric sinus is developed on the upper whorl surface, its culmination corresponding to the lower surface of the sub-sutural shoulder (Fig. 3G). The upper segment of the sinus is restricted to the narrow shoulder and is slightly prosocline. The lower segment extends from the base of the sub-sutural shoulder across the whorl face to the periphery; it is opisthocline, strongly oblique and without curvature. A narrow notch in the apertural margin may be present below the suture with the previous whorl, within the zone of the sub-sutural shoulder, but its absence from the transverse section (Fig. 4B) suggests that this was rapidly filled by shell deposition with subsequent growth. The basal lip is excavated, forming a shallow but uniformly concave (adaperturally) sinus extending from the periphery to the umbilicus (Fig. 3M).

Ornamentation consists of comarginal elements of two orders. Widely spaced, more prominent ribs are slightly lamellose and separated by several finer, parallel, striations (Fig. $3 \mathrm{H}$ ) which are not readily visible on all specimens. The lamellose ribs are often slightly nodose on the sub-sutural shoulder and peripheral angulation; the lamellae are not perpendicular to the whorl surface but are steeply inclined, almost parallel to the axis of coiling.

Ornamentation on the base is variably obscured by the sheet of parietal deposits which extends from the

A
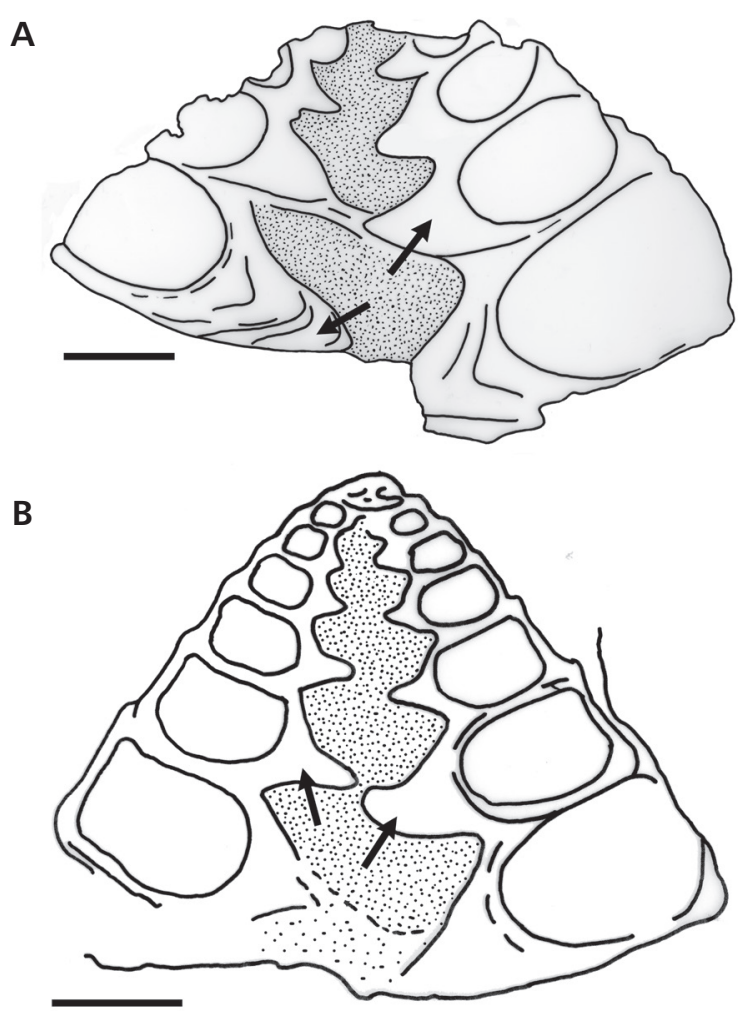

Figure 4. Axial sections with the sediment infilled umbilicus stippled; arrows indicate circumbilical funicles. - A - Grantlandispira christiei Peel, 1984, MGUH 16567 from GGU sample 82619, paratype, Silurian, Washington Land Group, Offley Island Formation, Kap Tyson, Hall Land, North Greenland. - B - Bobellis oliveri gen. et sp. nov., PMU 34888 from GGU sample 301325, Silurian, Washington Land Group, Samuelsen Høj Formation, east side of J.P. Koch Fjord, western Peary Land, North Greenland. Scale bars $=5 \mathrm{~mm}$. 
funicle towards the periphery (Fig. 3E), although the more prominent lamellose ribs may be discerned through this thin inductura.

The shell is relatively thin, but massively thickened in the vicinity of the funicle (Fig. 4B).

Discussion. - Specimens of Orecopia mccoyi (Walcott, 1884), the type species of Orecopia illustrated by Knight (1945), vary in profile from cyrtoconoid to somewhat gradate, but their periphery is more massive and rounded than in Bobellis oliveri. Additionally, the emargination on the upper whorl surface is more symmetrical than in Bobellis, where its lower margin projects more strongly, and with greater obliquity, towards the aperture (Fig. 3B, D, G). In this respect, the emargination in Bobellis oliveri closely resembles that in Grantlandispira christiei (Fig. 2C).

Bobellis oliveri is higher spired than Orecopia cotei Pedder, 1966 from the Devonian of British Columbia and Northwest Territories, Canada, and has a more pronounced sub-sutural shoulder and concave upper whorl surface. However, the shape of the apertural margin on the upper whorl surface of both species is similar (compare Fig. 3D, H with Pedder 1966, pl. 21, fig. 2). An additional specimen illustrated by Pedder (1966, pl. 21, fig. 7) from Northwest Territories, Canada, is somewhat atypical for the species in developing periodic node-like thickenings in the growth lines as they cross the shoulder, in which feature it resembles some specimens of Bobellis oliveri (Fig. 3G,L). Bobellis oliveri differs from Orecopia kadzielniae (Gürich, 1896), as described by Krawczyński (2002) from the Devonian (Frasnian) of Poland, in its greater number of whorls, concave upper whorl surface and the pronounced sub-sutural shoulder. Orecopia murrayi Tassell (1978) from the Lower Devonian of Victoria, Australia, is a low spired form without subsutural shouldering of the whorl or an angular periphery. The sinus on the upper whorl surface is much broader and shallower than in Bobellis oliveri. Tassell (1978) noted that a narrow umbilicus is sometimes present, suggesting the presence of an umbilical funcile, but the extent of this is not known.

Grantlandispira christiei lacks the prominent subsutural shoulder characteristic of Bobellis and its holotype develops a narrow peripheral cord (Fig. 2B, C, arrow) not present in Bobellis. Additionally, growth lines traversing the upper whorl surface are more strongly oblique in Bobellis than in Grantlandispira christiei. Species ?Grantlandispira acuta (Lindström, 1884, pl. 16, figs 1-6) from the Silurian Slite Beds of Gotland resembles Bobellis in its cyrtoconoid form but is lower spired, with a more acute periphery. It lacks the prominent subsutural shoulder and has less strongly inclined growth ornamentation below the sinus on the upper whorl sur- face. A circumbilical funicle is present but less strongly developed than in the G. christiei or Bobellis oliveri.

While similar in shell shape to Bobellis oliveri, Pycnomphalus trochiformis from Gotland lacks the prominent sub-sutural shoulder of the Greenland species (Fig. 3B).

\section{Acknowledgements}

Specimens of Bobellis oliveri were collected during regional geological campaigns (North Greenland Project 1978-80, 1984-85) organized by the Geological Survey of Greenland, now a part of the Geological Survey of Denmark and Greenland, Copenhagen, Denmark. Fruitful discussions with the late Radvan J. Horný (Prague) during the initial study of the material, and more recently with Jan Ove R. Ebbestad (Uppsala), are gratefully acknowledged. Jan Ove R. Ebbestad and Alexander Nützel (Munich) are thanked for reviews for the journal.

\section{References}

AktiPIs, S.W. \& GiribEt, G. 2010. A phylogeny of Vetigastropoda and other "archaeogastropods": re-organizing old gastropod clades. Invertebrate Biology 129, 220-240.

DOI 10.1111/j.1744-7410.2010.00198.x

Alexander, R.R. \& Dietl, G.P. 2003. The fossil record of shell-breaking predation on marine bivalves and gastropods, 141-176. In Kelley, P.H., Kowalewski, M. \& Hansen, T.A. (eds) Predator-prey Interactions in the Fossil Record. Kluwer Academic/Plenum Publishers, New York.

BAndel, K. \& Fryda, J. 1998. The systematic position of the Euomphalidae. Senckenbergiana lethaea 78, 103-131.

Blodgett, R.B. 1992. Taxonomy and paleobiogeographic affinities of an early Middle Devonian (Eifelian) Gastropod faunule from the Livengood Quadrangle, East-Central Alaska. Palaeontographica Abteilung A 221, 125-168.

Bouchet, P., Rocroi, J.-F., Frýda, J., Hausdorf, B., Ponder, W., VAldÉs, Á. \& WARÉn, A. 2005. Classification and nomenclator of gastropod families. Malacologia 47, 1-397.

Bouchet, P., Rocroi, J.-P., Hausdorf, B., Kaim, A., Kano, Y., Nützel, A., Parkhaev, P., Schrödl, M. \& Strong, E.E. 2017. Revised Classification, Nomenclator and Typification of Gastropod and Monoplacophoran Families. Malacologia 61, 1-526. DOI 10.4002/040.061.0201

Bronn, H.G. 1834. Lethaea Geognostica, oder Abbildungen und Beschreibungen der für die Gerbirgs-Formationem bezeichenstein Versteinerungen, Vol. 1. 96 pp. E. Schweizerbart's Verlagshandlung, Stuttgart.

Cox, L.R. \& Knight, J.B. 1960. Suborders of the Archaeogastropoda. Proceedings of the Malacological Society of London 33, 262-264.

CUVIER, G. 1797. Tableau élémentaire de l'histoire naturelle des animaux. 710 pp. Baudouin, Paris.

FRÝDA, J. 2012. Phylogeny of Palaeozoic gastropods inferred from their ontogeny, 395-435. In TALENT, J. (ed.) Earth and 
life: global biodiversity, extinction intervals and biogeographic pertubations through time. Springer Legacy Series, Berlin.

Frýda, J., Nützel, A. \& Wagner, P.J. 2008. Paleozoic gastropods, 239-296. In Ponder, W.F. \& Lindberg, D.R. (eds) Phylogeny and evolution of the Mollusca. University of California Press, Berkeley.

Gubanov, A.P., Peel, J.S. \& Pianovskaya, I.A. 1995. Softsediment adaptations in a new Silurian gastropod from Central Asia. Palaeontology 38, 831-842.

GÜRICH, G. 1896. Das Paläozoikum des Polnischen Mittelgebirge. Verhandlungen der Russischen Kaiserlichen Gesselschaft zu St.Petersburg II 32, 1-539.

Hadfield, M.G. 1970. Observations on the anatomy and biology of two California vermetid gastropods. The Veliger 12, 301-309.

Hall, J. 1852. Palceontology of New - York. Volume II. Containing descriptions of the organic remains of the lower Middle Division of the New - York System. 362 pp. C. Van Benthuysen, Albany.

Harper, J.A. 2016. Redescriptions of some Lower Devonian gastropods from Tennessee currently considered to be platyceratids. Journal of Paleontology 90, 195-210. DOI 10.1017/jpa.2016.50

Heidecker, E. 1959. Middle Devonian molluscs from the Burdekin Formation of North Queensland. Papers from the Department of Geology, University of Queensland 5(2), 3-8.

Heidelberger, D. 2001. Mitteldevonische (Givetische) Gastropoden (Mollusca) aus der Lahnmulde (suedliches Rheinisches Schiefergebirge). Geologische Abhandlungen Hessen 106, $1-291$.

Heidelberger, D. 2007. Neue Erkentnisse zu mikromorphen Gastropoden aus Sötenich (Givetium, Mittel-Devon). Paläontologische Zeitschrift 81, 229-237.

DOI 10.1007/BF02990174

Heidelberger, D. \& Bandel, K. 1999. Micromorph Gastropoda from the Middle Devonian (Givetian) limestone of the Sötenich Syncline (Eifel). Mitteilungen GeologiePaläontologie Institut der Universitat Hamburg 83, 129-162.

Higgins, A.K., Ineson, J.R., Peel, J.S., Surlyk, F. \& SønderHOLM, M. 1991. Lower Palaeozoic Franklinian Basin of North Greenland. Grønlands Geologiske Undersøgelse Bulletin 160, 71-139.

HorNÝ, R.J. 1995. Adapertural location of the retractor muscle attachment area in Oriostoma (Mollusca, Gastropoda): a consequence of mode of life. Časopis Národního muzea 164, 39-44.

Hughes, H.E. \& Thomas, A.T. 2015. Trilobites from the Silurian Reefs in North Greenland. Special Papers in Palaeontology 92, 1-93.

Ineson, J.R. \& Peel, J.S. 2011. Geological and depositional setting of the Sirius Passet Lagerstätte (Early Cambrian), North Greenland. Canadian Journal of Earth Sciences 48, 1259-1281. DOI 10.1139/e11-018

Kaim, A., Nützel, A. \& Maekawa, T. 2014. Gastropods, 167-184. In Shigeta, Y., Komatsu, T., Maekawa, T. \& Dang, H.T. (eds) Olenekian (Early Triassic) stratigraphy and fossil assemblages in northeastern Vietnam. National Museum of Nature and Science Monographs 45.

Kase, T. 1989. Autecology of Labrocuspis, a Middle Devonian omphalotrochid gastropod. Lethaia 22, 149-157. DOI 10.1111/j.1502-3931.1989.tb01677.x

Kase, T. \& Nishida, T. 1986. A Middle Devonian gastropod faunule from the Nakazato Formation of Kitakami, Northeast Japan. Bulletin of the National Science Museum, Tokyo, Series C (Geology and Paleontology) 12, 73-89.

Ketwetsuriya, C., Nützel, N. \& Kanjanapayont, P. 2016. Permian gastropods from the Tak Fa Limestone, Nakhon Sawan, Northern Thailand. Bulletin of Geosciences 91, 481513. DOI 10.3140/bull.geosci.1617

Knight, J.B. 1941. Paleozoic gastropod genotypes. Geological Society of America Special Paper 32, 1-510.

Knight, J.B. 1945. Some new genera of Paleozoic Gastropoda. Journal of Paleontology 19, 573-587.

Knight, J.B., Batten, R.L. \& Yochelson, E.L. 1960. Paleozoic gastropods, 169-331. In Moore, R.C. (ed.) Treatise on invertebrate paleontology, Part I, Mollusca 1. University of Kansas Press, Lawrence.

KoKEn, E. 1897. Die Gastropoden des baltischen Untersilurs. Bulletin de l'Académie Impériale des Sciences de St. Pétersbourg, Série 5, 7, 1-214.

Koken, E. \& Perner, J. 1925. Die Gastropoden den baltischen Untersilurs. Mémoires de l'Académie des Sciences de Russie, Serie 8, Classe physico-mathematique 37, 1-326.

KonINCK, L.G. DE 1881. Faune du calcaire carbonifière de la Belgique. 3. Gastéropodes. Mémoires du Musée Royal d'Historie Naturelle Belgique, Série Paléontologique 6, 1-170.

KraWCZyński, W. 2002. Frasnian gastropod synecology and bio-events in the Dyminy reef complex of the Holy Cross Mountains, Poland. Acta Palaeontologica Polonica 47, 267-288.

LindBerg, D.R. 1988. The Patellogastropoda, 35-64. In Ponder, W.F. (ed.) Prosobranch Phylogeny. Malacological Review Supplement 4.

Lindström, G. 1884. On the Silurian Gastropoda and Pteropoda of Gotland. Kongliga Svenska Vetenskaps-Akademiens Handlingar 19, 1-250.

Lindström, A. \& PeEl, J.S. 1997. Failed predation and shell repair in the gastropod Poleumita from the Silurian of Gotland, Sweden. Věstník Českého geologického ústavu 72, 115-126.

Linsley, R.M. 1977. Some "laws" of gastropod shell form. Paleobiology 3, 196-206. DOI 10.1017/S0094837300005261

Linsley, R.M. 1978. The Omphalocirridae: a new family of Palaeozoic Gastropoda which exhibits sexual dimorphism. Memoirs of the National Museum of Victoria 39, 33-54. DOI 10.24199/j.mmv.1978.39.03

Linsley, R.M. \& Kier, W.M. 1984. The Paragastropoda: a proposal for a new class of Paleozoic Mollusca. Malacologia 25, 241-254.

LinsLey, R.M. \& Yochelson, E.L. 1973. Devonian carrier shells (Euomphalidae) from North America and Germany. U.S. Geological Survey Professional Paper 824, 1-23. 
McLean, J.H. 1981. The Galapagos rift limpet Neomphalus: relevance to understanding the evolution of a major Paleozoic-Mesozoic radiation. Malacologia 21, 291-336.

McNair, C.G., Kier, W.M., Lacroix, P.D. \& Linsley, R.M. 1981. The functional significance of aperture form in gastropods. Lethaia 14, 63-70. DOI 10.1111/j.1502-3931.1981.tb01076.x

MeEK, F.B. 1873. Descriptions of the invertebrate fossils of the Silurian and Devonian systems. Geological Survey of Ohio 1(2), 1-243.

Meek, F.B. \& Worthen, A.H. 1867. Descriptions of invertebrates from the Carboniferous System, Illinois. Geological Survey of Illinois 2, 145-411.

Nakano, T. \& Ozawa, T. 2007. Worldwide phylogeography of limpets of the order Patellogastropoda: molecular, morphological and palaeontological evidence. Journal of Molluscan Studies 73, 79-99. DOI 10.1093/mollus/eym001

NütZel, A. 2002. An evaluation of the recently proposed Palaeozoic gastropod subclass Euomphalomorpha. Palaeontology 45, 259-266. DOI 10.1111/1475-4983.00236

Nützel, A. \& Nakazawa, K. 2012. Permian (Capitanian) gastropods from the Akasaka Limestone (Gifu Prefecture, Japan). Journal of Systematic Palaeontology 10, 103-169. DOI 10.1080/14772019.2010.549659

PARKS, W.A. 1915. Palaeozoic fossils from a region southwest of Hudson Bay. A description of the fossils collected by Joseph B. Tyrrell, Esq., F.R.S.C., in the District of Patricia, Ontario, and in northern Manitoba during the summer of 1912. Transactions of the Royal Canadian Institute 11, 1-95.

Pedder, A.E.H. 1966. The Upper Devonian gastropod Orecopia in western Canada. Palaeontology 9, 142-147.

Peel, J.S. 1975. A new Silurian gastropod from Wisconsin and the ecology of uncoiling in Palaeozoic gastropods. Bulletin of the Geological Society of Denmark 24, 211-221.

Peel, J.S. 1984. Autecology and systematics of a new Silurian anomphalid gastropod from western North Greenland. Rapport Grønlands Geologiske Undersøgelse 121, 77-87.

PeEL, J.S. 2018. Teller's operculum; revising a rare operculate gastropod from the Silurian of Wisconsin (Laurentia). Bulletin of Geosciences 93, 499-511.

DOI 10.3140/bull.geosci.1725

Peel, J.S. \& Sønderholm, M. (eds) 1991. Sedimentary basins of North Greenland. Grønlands Geologiske Undersøgelse Bulletin 160, 1-164.

Perner, J. 1903. Systême Silurien du centre de la Bohême par Joachim Barrande. Vol. IV Gastéropodes 1, Texte (Patellidae et Bellerophontidae) et Planches 1 à 89.164 pp. C. Bellman, Prague.

Perner, J. 1907. Systême Silurien du centre de la Bohême par Joachim Barrande. Vol. IV Gastéropodes 2, Texte et Planches 90-175. 380 pp. C. Bellman, Prague.

Ponder, W.F. \& LindberG, D.R. 1997.Towards a phylogeny of gastropod molluscs: an analysis using morphological characters. Zoological Journal of the Linnean Society 119, 83-265. DOI 10.1111/j.1096-3642.1997.tb00137.x

Rafinesque, C.S. 1815. Analyse de la nature ou tableau de l'univers et des corps organisés. 223 pp. Palerme.

Robertson, R. 1967. Heliacus (Gastropoda: Architectonicidae) symbiotic with Zoanthiniaria (Coelenterata). Science 156, 246-248. DOI 10.1126/science.156.3772.246

Robertson, R. 1970. The feeding, larval dispersal and metamorphosis of Phillipia (Gastropoda: Architectonicidae). Pacific Science 24, 378-388.

RoHr, D.M. 2004. Life association of shell and operculum of Ceratopea Ulrich 1911 (Ordovician, Gastropoda). Journal of Paleontology 78, 218-220.

DOI 10.1666/0022-3360(2004)078<0218:LAOSAO >2.0.CO;2

Rohr, D.M. \& Boucot, A.J. 1984. Observations of the operculum of Oriostoma (Silurian Gastropoda). Canadian Journal of Earth Sciences 22, 294-296. DOI 10.1139/e85-026

RoHr, D.M. \& Gubanov, A.P. 1997. Macluritid opercula (Gastropoda) from the Middle Ordovician of Siberia and Alaska. Journal of Paleontology 71, 394-400.

DOI 10.1017/S002233600003941X

Rohr, D.M. \& Yochelson, E.L. 1999. Life association of shell and operculum of Middle Ordovician gastropod Maclurites. Journal of Paleontology 73, 1078-1080. DOI 10.1017/S0022336000030997

Rohr, D.M., Fix, M.F. \& Darrough, G. 2004. Life association of shell and operculum of Ceratopea Ulrich, 1911 (Ordovician; Gastropoda). Journal of Paleontology 78, 218-220. DOI 10.1666/0022-3360(2004)078<0218:LAOSAO >2.0.CO;2

SurlyK, F. 1991. Tectonostratigraphy of North Greenland. Grønlands Geologiske Undersøgelse Bulletin 160, 25-47.

Tassell, C.B. 1978. Gastropods from the early Devonian Bell Point Limestone, Cape Liptrap Peninsula, Victoria. Memoirs of the National Museum of Victoria 39, 19-32. DOI 10.24199/j.mmv.1978.39.02

Vermeis, G. 1987. Evolution and escalation: an ecological history of life. 527 pp. Princeton University Press, Princeton.

Wagner, P.J. 2002. Phylogenetic relationships of the earliest anisostrophically coiled gastropods. Smithsonian Contributions to Paleobiology 88, 1-152. DOI 10.5479/si.00810266.88.1

Wagner, P.J. \& ERwin, D.H. 2006. Patterns of convergence in general shell form among Paleozoic gastropods. Paleobiology 32, 316-337. DOI 10.1666/04092.1

Walcott, C.D. 1884. Geology of the Eureka district, Nevada, with an atlas. Monographs of the United States Geological Survey 20, 1-419.

Waterhouse, J.B. 1963. Permian gastropods of New Zealand. Part 1-Bellerophontacea and Euomphalacea. New Zealand Journal of Geology \& Geophysics 6, 88-112. DOI 10.1080/00288306.1963.10420091

Wenz, W. 1938-1944. Teil 1: Allgemeiner Teil und Prosobranchia. In Schindewolf, O.H. (ed.) Handbüch der Paläzoologie, Band 6, Gastropoda. 1639 pp. Gebrüder Bornträger, Berlin.

White, C.A. 1877. Report upon the invertebrate fossils collected in portions of Nevada, Utah, Colorado, New Mexico and Arizona, by parties of the expeditions of 1871, 1872, 1873, and 1874. Report upon United States geographical surveys west of the one hundredth meridian. Vol. 4, Paleontology. 219 pp.

Whiteaves, J.F. 1884. On some new, imperfectly characterized 
or previously unrecorded species of fossils from the Guelph Formation of Ontario. Palaeozoic Fossils 3(1), 1-43.

DOI 10.4095/131596

Whiteaves, J.F. 1895. Revision of the fauna of the Guelph formation of Ontario, with descriptions of a few new species. Palaeozoic Fossils 3(2), 45-109. DOI 10.4095/131597

Whiteaves, G.F. 1906. Revised list of the fossils of the Guelph formation of Ontario. Palceozoic fossils 3, part 4, 327-340.

Yochelson, E.L. 1956. Permian Gastropoda of the southwestern United States: I. Euomphalacea, Trochonematacea, etc. Bulletin of the American Museum of Natural History 110, 173-260.
Yochelson, E.L. 1971. A new late Devonian gastropod and its bearing on problems of open coiling and septation. Smithsonian Contributions to Paleobiology 3, 231-241.

Yochelson, E.L. 1979. Gastropod opercula as objects for paleobiogeographic study, 37-43. In GraY, J. \& Boucot, A.J. (eds) Historical biogeography, plate tectonics, and the changing environment. Oregon State University Press, Corvallis, Oregon.

Yochelson, E.L. \& Linsley, R.M. 1972. Opercula of two gastropods from the Lilydale Limestone (Early Devonian) of Victoria, Australia. Memoirs of the National Museum of Victoria 33, 1-13. DOI 10.24199/j.mmv.1972.33.01 